\title{
Pengujian Data Warehouse SOLAP untuk Komoditas Pertanian Indonesia
}

\section{Data Warehouse Testing in SOLAP for Indonesia Agricultural Commodities}

\author{
FARAH GHITA $^{1 *}$, RINA TRISMININGSIH $^{1}$
}

\begin{abstract}
Abstrak
Pengujian merupakan tahapan yang sangat penting dalam pengembangan data warehouse, karena analisis dan keputusan dibuat berdasarkan informasi yang dihasilkan dari data warehouse. Terdapat sistem yang memungkinkan analisis pada data spasial dengan interaktif dan efisien, yaitu sistem spatial OLAP (SOLAP). Dalam pembangunan data warehouse terdapat tahapan penting, yaitu proses extract, transform, load (ETL). Penelitian ini melakukan pengujian data warehouse, khususnya pengujian modul ETL pada SOLAP komoditas pertanian Indonesia yang telah dikembangkan pada penelitian sebelumnya. Hasil pengujian proses ETL menunjukkan adanya ketidaksesuaian antara data sumber dan data warehouse. Dalam penelitian ini, pengujian modul ETL dilakukan dengan pengujian fungsional, yaitu memvalidasi data target dengan data sumber. Pengujian modul ETL diawali dengan membuat source-to-target mappings dan aturan kualitas data sebagai acuan untuk pembuatan kasus uji. Pengujian proses ETL terdiri atas pengujian kualitas data dan keseimbangan data yang dilakukan dengan menjalankan kueri pada sistem manajemen basis data (DBMS). Pengujian keseimbangan data menggunakan metode simple random sampling dan systematic sampling. Hasil pengujian dianalisis dan ditemukan letak kesalahan pengembangan pada proses ETL, tampilan aplikasi SOLAP dan pengambilan data sumber.
\end{abstract}

Kata Kunci: Data warehouse, ETL, komoditas pertanian, pengujian data warehouse.

\begin{abstract}
Testing is a very important stage in the development of a data warehouse, because analysis and decisions are made based on information generated from the data warehouse. There is a system that allowing efficient and interactive analysis, namely Spatial Online Analytical Processing systems (SOLAP). In data warehouse development, there is an important stage, namely extract, transform, load (ETL). This research tested the data warehouse, specifically the ETL module in SOLAP for Indonesia agricultural commodities that had been developed in previous research. The test results of the ETL process indicated a discrepancy between the source data and the data warehouse. In this research, ETL module was tested by functional testing, where the target data is validated by the source data. Testing the ETL module begins with creating source-to-target mappings and data quality rules as reference for making test cases. Testing the ETL process consists of data quality test and balancing test by running queries on the database management system (DBMS). Simple random sampling and systematic sampling methods were done for balancing test. The test results were analyzed and showed the fault of the development, which is in the ETL process, the SOLAP application and retrieval of data sources.
\end{abstract}

Keywords: Agricultural commodity, data warehouse, data warehouse testing, ETL.

\section{PENDAHULUAN}

Kementerian Pertanian (Kementan) Republik Indonesia menghimpun data komoditas yang merupakan hasil dari subsektor perkebunan, peternakan, tanaman pangan, dan juga hortikultura di seluruh Indonesia. Penghimpunan data tersebut dapat diakses di situs Kementan Republik Indonesia. Pembuatan modul ETL untuk data warehouse komoditas pertanian Indonesia telah dilakukan pada penelitian sebelumnya oleh Sitanggang et al. (2016). Penelitian tersebut mengembangkan modul ETL untuk menyimpan pembaruan data dan informasi dalam

${ }^{1}$ Departemen Ilmu Komputer IPB, 0251-8625584;

*Penulis Korespondensi: Tel/Faks: 0251-8625584; Surel: farahghita@ymail.com 
SOLAP untuk komoditas pertanian Indonesia. Dalam penelitian tersebut digunakan data spasial yaitu peta digital perbatasan kabupaten dan data non-spasial yang diperoleh dari Basis Data Statistik Pertanian. Pemodelan ETL dalam penelitian tersebut dilakukan menggunakan Business Process Modeling Notation (BPMN) untuk pemodelan konseptual dan arsitektur graf untuk desain logis. Pengembangan modul ETL tersebut telah berhasil dilakukan, pengujian sistem juga menunjukan modul ETL bekerja dengan benar dalam memperbaharui data warehouse yang terintegrasi ke SOLAP (Sitanggang et al. 2016). Walaupun pengujian telah dinyatakan berhasil dan sesuai, setelah dilakukan peninjauan ulang, masih ada perbedaan antara data sumber dan data warehouse SOLAP dalam penelitian tersebut. Sebelumnya juga telah dilakukan pengujian usability untuk SOLAP komoditas pertanian Indonesia oleh Sitanggang et al. (2018), namun belum dilakukannya pengujian fungsional yang berguna untuk memastikan data pada data warehouse ditangkap dengan benar dari data sumber.

Data warehouse adalah basis data dari struktur data unik yang memungkinkan kinerja menjadi relatif cepat dan mudah dari kueri kompleks terhadap sejumlah data yang besar (Patel 2012). Tujuan dari data warehouse adalah membantu pengguna data membuat analisis dan keputusan menjadi lebih cepat dan lebih baik (Homayouni et al. 2018). Sebelum data disimpan ke dalam data warehouse, data biasanya perlu diolah menjadi bentuk data yang siap untuk dianalisis melalui proses extract, transform, load (ETL) (Caron et al. 2013). Proses ETL merupakan ekstraksi data dari berbagai sumber, pengubahan data ke bentuk yang sesuai dengan kebutuhan dan pengisian ke penyimpanan data warehouse (Wijaya dan Pudjoatmodjo 2016). Untuk menganalisis data spasial, sistem spatial OLAP (SOLAP) memungkinkan analisis pada data spasial dengan interaktif dan efisien dari kubus data spasial yang besar (Boulil et al. 2014).

Pengujian data warehouse merupakan tahapan yang sangat penting dalam pengembangan data warehouse karena analisis dan keputusan dibuat berdasarkan informasi yang dihasilkan dari data warehouse. Dalam proses pengembangan data warehouse, data melewati berbagai tahap yang masing-masing menyebabkan berbagai jenis perubahan pada data untuk mencapai pengguna. Hanya membandingkan keluaran dari sistem data warehouse dengan sumber data untuk menguji sistem data warehouse bekerja dengan benar bukan merupakan pendekatan terbaik. Setiap tahap dan setiap komponen yang dilewati data harus diuji untuk menjamin keakuratan, pelestarian kualitas data, atau bahkan peningkatannya (ElGamal et al. 2011). Pengujian data warehouse berfokus langsung pada data dan informasi, berbeda dengan pengujian perangkat lunak yang berfokus pada kode program (Golfarelli dan Rizzi 2009).

Penelitian ini melakukan pengujian modul ETL pada data warehouse SOLAP komoditas pertanian Indonesia yang telah dikembangkan oleh Sitanggang et al. (2016). Pengujian proses ETL dilakukan dengan melakukan analisis pada hasil uji kualitas dan keseimbangan data untuk mendapatkan letak kesalahan pada pengembangan modul tersebut jika ditemukannya ketidaksesuaian data. Penelitian ini diharapkan dapat menghasilkan pengujian dan analisis hasil uji yang memiliki akurasi tinggi. Tingkat akurasi hasil uji dapat dikategorikan tinggi jika pengujian dapat mewakili data secara keseluruhan dan jika ditemukan ketidaksesuaian data, hasil analisis juga dapat menemukan letak penyebab ketidaksesuaian data tersebut.

\section{METODE}

\section{Data Penelitian}

Terdapat dua jenis data yang digunakan pada penelitian ini, yaitu data sumber dan data target. Data sumber merupakan data hasil komoditas pertanian di Indonesia yang diperoleh dari situs Kementan Republik Indonesia pada alamat https://aplikasi2.pertanian.go.id/bdsp/, sedangkan data target diperoleh dari SOLAP komoditas pertanian Indonesia yang dapat diakses pada alamat http://solap.apps.cs.ipb.ac.id/. Penelitian ini menggunakan data komoditas dari seluruh subsektor dengan rentang waktu dari tahun 1970 hingga 2018.

\section{Tahapan Penelitian}


Penelitian ini terbagi menjadi beberapa tahapan, yaitu akuisisi data, pembuatan sourceto-target mappings, pembuatan kasus uji, pengujian proses ETL dan analisis hasil uji. Tahapan pengujian proses ETL terdiri atas uji validasi data dan uji keseimbangan data menggunakan sampling. Diagram tahapan penelitian dapat dilihat pada Gambar 1.

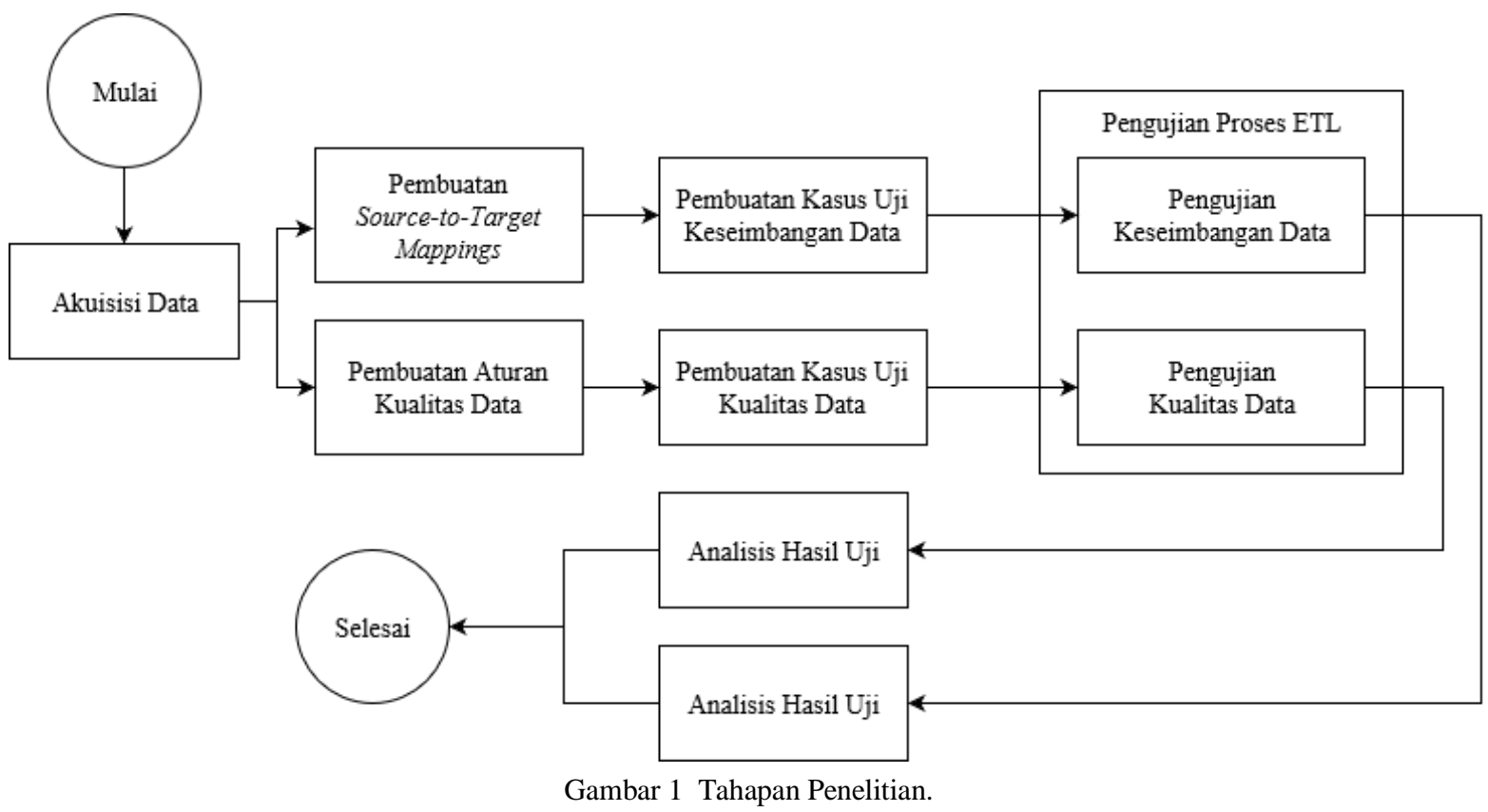

\begin{abstract}
Akuisisi Data
Terdapat tiga buah data yang digunakan dalam penelitian ini. Data pertama diperoleh dari situs Kementan Indonesia pada alamat https://aplikasi2.pertanian.go.id/bdsp/ yang dijadikan data sumber, data kedua, dan ketiga adalah data target yang terdiri atas SOLAP komoditas pertanian Indonesia pada alamat http://solap.apps.cs.ipb.ac.id dan data warehouse dalam DBMS yang dibangun pada penelitian sebelumnya. Data yang digunakan meliputi subsektor tanaman pangan, hortikultura, perkebunan, dan peternakan yang dikumpulkan per tahun dimulai dari tahun 1970 hingga tahun 2018.
\end{abstract}

\title{
Pembuatan Source-to-Target Mappings dan Aturan Kualitas Data
}

Source-to-target mappings merupakan turunan dari transformasi dalam proses ETL yang dapat dideskripsikan dalam bentuk dokumen, spreadsheet, Entity Relationship (ER) diagram, atau skrip SQL (Homayouni et al. 2018). Pada tahapan ini dilakukan pembuatan source-to-target mappings yang disajikan dalam bentuk tabel berisi informasi yang menggambarkan bagaimana satu atau lebih atribut dalam tabel sumber berkaitan dengan satu atau lebih atribut di data target atau data warehouse. Contoh source-to-target mappings menurut Homayouni et al. (2018) ditunjukkan pada Tabel 1.

Aturan kualitas data disajikan dalam bentuk tabel yang berisi informasi penilaian kualitas data pada data warehouse. Aturan kualitas data dibuat dengan menilai kriteria data berdasarkan pada dimensi kualitas data. Contoh aturan kualitas data menurut Homayouni et al. (2018) ditunjukkan pada Tabel 2.

\section{Pembuatan Kasus Uji Keseimbangan dan Kualitas Data}

Dalam tahapan ini, dilakukan perincian langkah-langkah pengujian dengan hasil yang diharapkan. Uji kasus dibuat berdasarkan source-to-target mappings dan aturan kualitas data yang telah dibuat sebelumnya. Dalam tahapan ini juga dibuat kueri workload atau kueri yang dijalankan pengguna terhadap data target dibuat untuk pengujian proses ETL. 
Tabel 1 Contoh struktur tabel mappings tanpa pernyataan (Homayouni et al. 2018)

\begin{tabular}{|c|c|c|c|c|}
\hline Mappings & Source table & Condition & Source coloumn & Target table \\
\hline 1-1 table & Address & Year>2000 & & Location \\
\hline *-1 table & $\begin{array}{l}\text { [0]:Patient } \\
\text { [1]:Concept } \\
\text { Operation: } \\
\text { LEFT JOIN }\end{array}$ & IsCurrent= & & Person \\
\hline *-1 attribute & Patient & IsCurrent= & $\begin{array}{l}\text { [0]:Weight } \\
{[1]: \text { Height }} \\
\text { Operation: BMI }\end{array}$ & Person \\
\hline 1-1 attribute & $\begin{array}{l}\text { [0]:Patient } \\
\text { [1]:Concept } \\
\text { Operation: } \\
\text { LEFT JOIN }\end{array}$ & IsCurrent= & Concept_code & Person \\
\hline 1-1 attribute & Address & Year $>2000$ & Address_Key & Location \\
\hline 1-1 attribute & Address & Year $>2000$ & City & Location \\
\hline
\end{tabular}

Tabel 2 Contoh tabel aturan kualitas data (Homayouni et al. 2018)

\begin{tabular}{clll}
\hline Rule_id & Data quality rule & Status & Description \\
\hline 19 & Year of birth should not be prior & warning & $\begin{array}{l}\text { Checks whether or not year of birth is less } \\
\text { to } 1800\end{array}$ \\
& $\begin{array}{l}\text { Percentage of patients with no } 1800 \\
\text { visits should not exceed a } \\
\text { threshold value }\end{array}$ & notification & $\begin{array}{l}\text { Checks whether or not the percentage of } \\
\text { patiens that have no visit records is greater } \\
\text { than 5 }\end{array}$ \\
\hline
\end{tabular}

\section{Pengujian Proses ETL}

Dalam penelitian ini, dilakukan pengujian fungsional dengan cara menguji kualitas data dan keseimbangan data.

1 Uji kualitas data

Pengujian ini memverifikasi konsistensi data yang dimuat ke dalam data warehouse melewati proses ETL dengan data model dan kebutuhan organisasi (Homayouni 2018). Pengujian ini dilakukan dengan menjalankan kueri yang telah dibuat berdasarkan tabel aturan kualitas data untuk memverifikasi kualitas data yang ada di dalam data warehouse.

2 Uji keseimbangan data

Pengujian ini memastikan bahwa data yang diperoleh dari data sumber tidak hilang atau salah dimodifikasi oleh proses ETL (Homayouni 2018). Pengujian ini menggunakan source-to-target mappings sebagai acuan untuk memverifikasi data yang ada pada data sumber dan data target. Pengujian ini tidak dilakukan dengan menguji seluruh data sumber dan data target, melainkan hanya mengambil beberapa data sampel, pengambilan data sampel menggunakan metode simple random sampling dan systematic sampling.

\section{Analisis Hasil Uji}

Dalam tahapan ini, setiap hasil pengujian pada tahapan pengujian proses ETL dianalisis. Apabila ada perbedaan data atau kesalahan dalam proses ETL, laporan kesalahan akan dibuat dan penyebab kesalahan dalam pengembangan akan dijelaskan.

\section{HASIL DAN PEMBAHASAN}

\section{Akuisisi Data}

Data yang digunakan merupakan data hasil komoditas pertanian Indonesia yang meliputi empat subsektor, yaitu tanaman pangan, holtikultura, perkebunan, dan peternakan. Setiap subsektor mempunyai indikator masing-masing dengan satuan nilai yang berbeda-beda. Tanaman pangan dan holtikultura mempunyai tiga indikator, yaitu luas panen, produksi, dan produktivitas. Perkebunan mempunyai tiga indikator, yaitu luas areal, produksi, dan produktivitas. Peternakan mempunyai dua indikator, yaitu populasi dan produksi. Data komoditas tersebut diambil dari 34 provinsi di Indonesia berdasarkan pada kabupaten di tiaptiap provinsi dimulai dari tahun 1970 hingga tahun 2018. 
Data sumber yang digunakan dalam penelitian ini diperoleh dari situs Kementan Indonesia pada https://aplikasi2.pertanian.go.id/bdsp/. Data dari situs tersebut telah dilakukan scraping menjadi 5699 fail dalam format .xls. Setiap fail berisi data komoditas tahun 1970 hingga tahun 2018 dari masing-masing kabupaten. Contoh isi fail data sumber tersebut dapat dilihat pada Gambar 2.

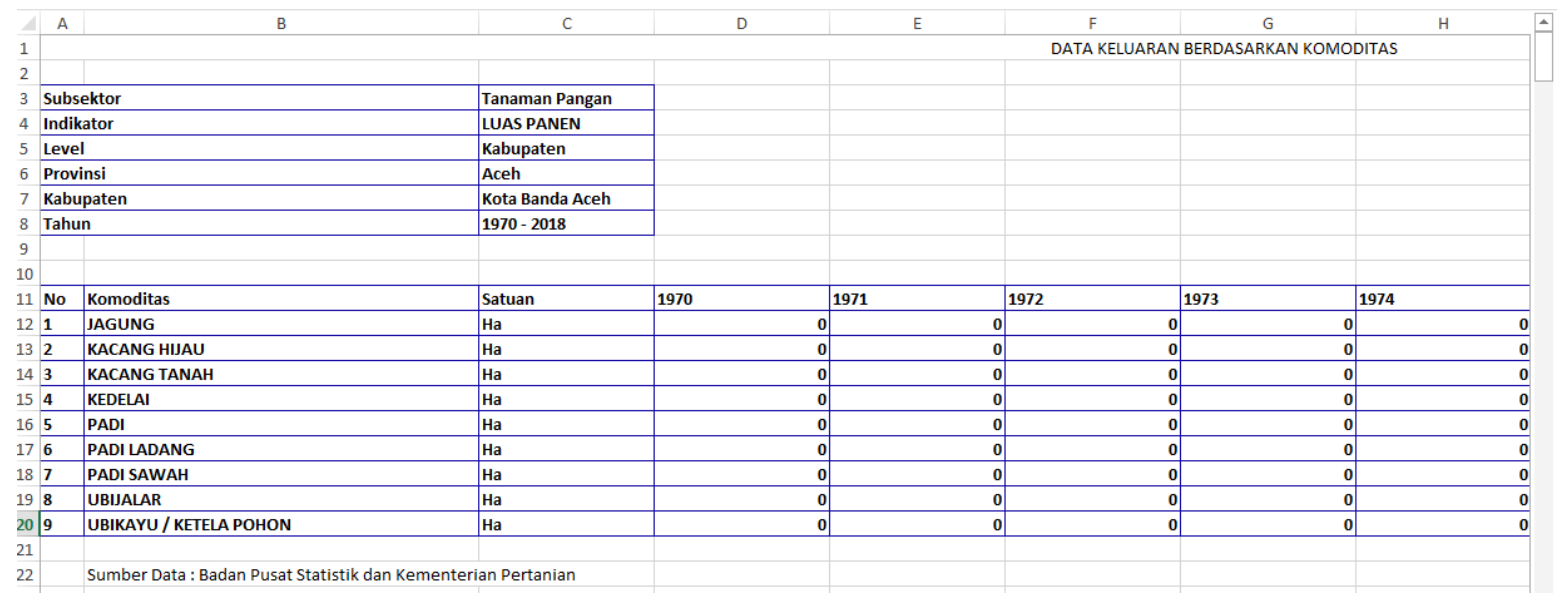

Gambar 2 Isi fail data sumber hasil komoditas pertanian Indonesia.

Data target yang digunakan dalam penelitian ini adalah SOLAP komoditas pertanian Indonesia yang dapat diakses pada alamat http://solap.apps.cs.ipb.ac.id dan data warehouse pada DBMS yang telah dibangun pada penelitian sebelumnya. Data yang digunakan pada website SOLAP berbentuk tabel dengan judul baris berupa komoditas dan judul kolom berupa waktu. Contoh isi data target pada SOLAP tersebut dapat dilihat pada Gambar 3. Data warehouse pada DBMS yang digunakan untuk SOLAP tersebut didapatkan dari pengembang aplikasi. Contoh isi nilai data pada DBMS yang telah didapatkan dapat dilihat pada Gambar 4.

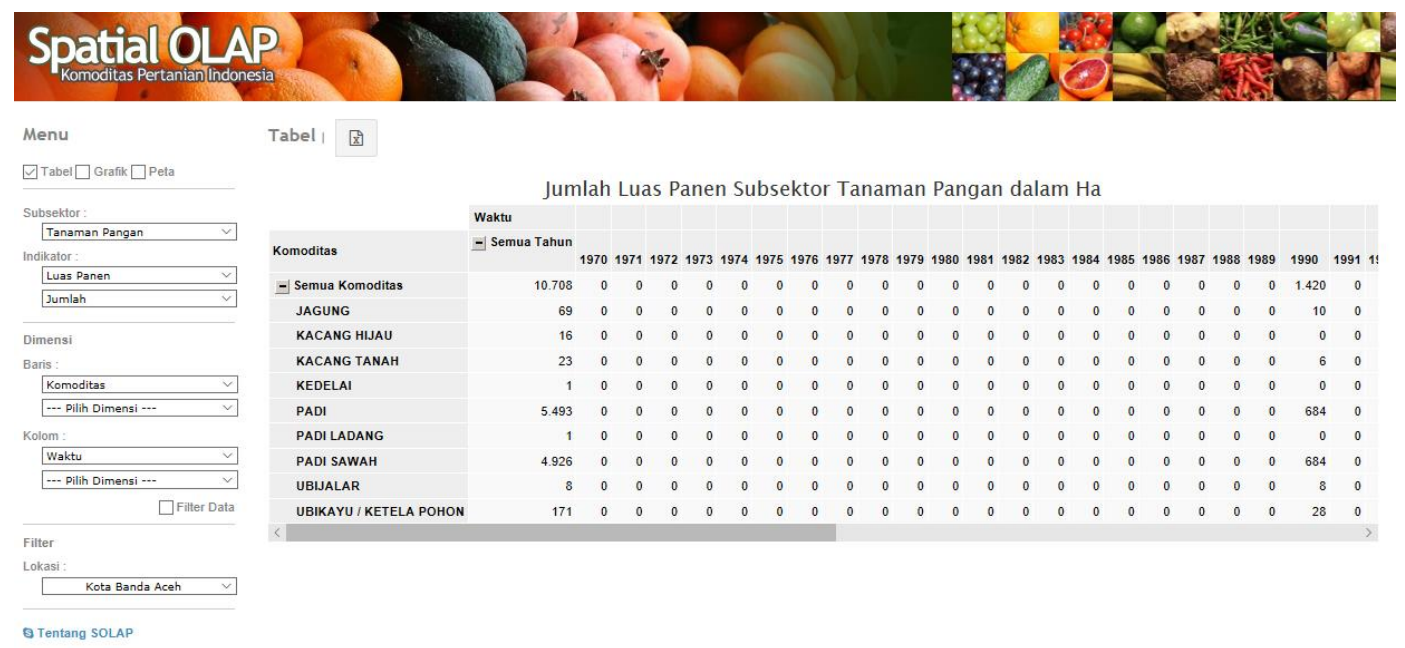

Gambar 3 Contoh isi data target pada SOLAP komoditas pertanian Indonesia.

\section{Pembuatan Source-to-Target Mappings dan Aturan Kualitas Data}

Source-to-target mappings dibuat berdasarkan pada skema dan pemodelan ETL yang telah dibuat dalam penelitian sebelumnya. Source-to-target mappings merupakan tabel yang menggambarkan pemetaan data dari data sumber ke data target. Terdapat 9 atribut dalam tabel ini, yaitu code, mapping, source table, source column, source type, condition, target table, target column, dan target type. Atribut code menunjukkan nomor atau pengodean untuk mapping. Atribut mapping pada tabel menunjukkan tipe mapping, terdapat 4 jenis mapping menurut Homayouni (2018), yaitu one-to-one attribute, one-to-one table, many-to-one 
attribute, dan many-to-one table. Atribut source table, source column dan source type menunjukkan keterangan tabel, kolom, dan tipe data pada data sumber. Atribut condition menunjukkan kondisi yang berlaku pada data sumber untuk masuk ke dalam data target. Atribut target table, target column, dan target type menunjukkan keterangan tabel, kolom, dan tipe data pada data target.

\begin{tabular}{|c|c|c|c|c|c|c|c|c|c|}
\hline \multicolumn{2}{|c|}{ Query Editor } & \multicolumn{8}{|c|}{ Query History } \\
\hline 1 & SELECT & * FROM & public.fa & $c t$ food_c & crops WHERE I & cation_id=6 & & & \\
\hline \multicolumn{2}{|c|}{ Data Output } & \multirow{2}{*}{$\begin{array}{l}\text { Explain } \\
\text { dity_id }\end{array}$} & Messages & \multicolumn{6}{|c|}{ Notifications } \\
\hline$\Delta$ & $\begin{array}{l}\text { commodí } \\
\text { integer }\end{array}$ & & $\begin{array}{l}\text { location_id } \\
\text { integer }\end{array}$ & $\begin{array}{l}\text { time_id } \\
\text { integer }\end{array}$ & $\begin{array}{l}\text { harvested_area } \\
\text { numeric }\end{array}$ & $\begin{array}{l}\text { production } \\
\text { numeric }\end{array}$ & $\begin{array}{l}\text { productivity } \\
\text { numeric }\end{array}$ & $\begin{array}{l}\text { id } \\
\text { integer }\end{array}$ & \\
\hline 1 & & 79 & 60 & 1 & 0. & 0.0 & 0.0 & 36342 & $\hat{\imath}$ \\
\hline 2 & & 79 & 60 & 2 & 0. & 0.0 & 0.0 & 36343 & \\
\hline 3 & & 79 & 60 & 3 & 0. & 0.0 & 0.0 & 36344 & \\
\hline 4 & & 79 & 60 & 4 & 0. & 0.0 & 0.0 & 36345 & \\
\hline 5 & & 79 & 60 & 5 & 0. & 0.0 & 0.0 & 36346 & \\
\hline 6 & & 79 & 60 & 6 & 0. & 0.0 & 0.0 & 36347 & \\
\hline 7 & & 79 & 60 & 7 & 0. & 0.0 & 0.0 & 36348 & \\
\hline 8 & & 79 & 60 & 8 & 0. & 0.0 & 0.0 & 36349 & \\
\hline 9 & & 79 & 60 & 9 & 0. & 0.0 & 0.0 & 36350 & \\
\hline 10 & & 79 & 60 & 10 & 0. & 0.0 & 0.0 & 36351 & $\checkmark$ \\
\hline
\end{tabular}

Gambar 4 Contoh isi data pada DBMS untuk SOLAP komoditas pertanian Indonesia.

One-to-one attribute dan many-to-one attribute menunjukkan atribut pada data target dimuat dari satu tabel pada data sumber. One-to-one table dan many-to-one table menunjukkan atribut pada data target dimuat dari beberapa tabel pada data sumber. Seluruh mappings yang dibuat pada penelitian ini memiliki many-to-one table yang dituliskan dengan *-1 sebagai jenis mapping karena setiap atribut pada tabel data target dimuat dari banyak tabel pada data sumber yang merupakan spreadsheet.

Aturan kualitas data atau data quality rules merupakan tabel yang berisi daftar persyaratan atau karakteristik isi data yang ada di dalam data target. Nilai pada data target diharapkan sama dengan nilai yang ada pada data sumber sehingga aturan kualitas data yang diterapkan pada data target mengacu pada kualitas data yang ada pada data sumber. Aturan kualitas data dibuat dengan melihat data sumber secara keseluruhan lalu menilai karakteristik data pada atribut-atribut dalam tabel. Aturan kualitas data digunakan untuk mengidentifikasi perbedaan karakteristik data antara data target dan data sumber. Dimensi data yang digunakan pada aturan kualitas data ini adalah dimensi konsistensi dan akurasi karena pengujian yang dilakukan hanya untuk memverifikasi nilai data antara data target dan data sumber. Tabel aturan kualitas data dapat dilihat pada Tabel 3. Aturan kualitas data berlaku untuk setiap atribut yang dicantumkan dalam kolom atribut. Aturan kualitas data yang ada pada Tabel 3 berlaku untuk seluruh tabel pada data target yang memiliki nama atribut yang sama.

Tabel 3 Aturan kualitas data

\begin{tabular}{|c|c|c|c|}
\hline Kode & Atribut & Aturan Kualitas Data & Deskripsi \\
\hline Q-1 & $\begin{array}{l}\text { harvested_area, acreage, } \\
\text { production, productivity, } \\
\text { population }\end{array}$ & $\begin{array}{l}\text { Ketelitian data sesuai dengan } \\
\text { sumber, tanpa pembulatan }\end{array}$ & $\begin{array}{l}\text { Mengecek apakah ada data yang memiliki } \\
\text { ketelitian berbeda dengan sumber }\end{array}$ \\
\hline Q-2 & $\begin{array}{l}\text { harvested_area, acreage, } \\
\text { production, productivity, } \\
\text { population }\end{array}$ & Data tidak boleh null & $\begin{array}{l}\text { Mengecek apakah ada data yang memiliki } \\
\text { nilai null }\end{array}$ \\
\hline Q-3 & $\begin{array}{l}\text { Harvested_area, acreage, } \\
\text { production, productivity, } \\
\text { population }\end{array}$ & Data tidak boleh negatif & $\begin{array}{l}\text { Mengecek apakah ada data yang memiliki } \\
\text { nilai kurang dari } 0\end{array}$ \\
\hline
\end{tabular}




\section{Pembuatan Kasus Uji}

Kasus uji dibuat dalam bentuk tabel, tabel ini terdiri atas empat atribut, yaitu id, deskripsi, contoh kueri dan ekspektasi hasil. Atribut id merupakan kode kasus uji, atribut deskripsi menunjukkan penjelasan kasus uji, atribut contoh kueri menunjukkan salah satu sampel kueri untuk kasus uji tersebut yang dijalankan pada DBMS data target saat pengujian proses ETL dan atribut ekspektasi hasil merupakan keluaran yang diharapkan setelah dilakukan pengujian proses ETL. Contoh kueri pada kasus uji dijelaskan dalam tabel yang berbeda, tabel tersebut meliputi empat atribut, yaitu id, tabel uji, atribut uji, dan deskripsi kueri. Berikut kasus uji yang dibuat:

1 Kasus uji keseimbangan data

Kasus uji ini dibuat untuk melakukan uji keseimbangan data pada pengujian proses ETL. Tabel 4 menunjukkan kasus uji yang dibuat, kasus uji dibuat untuk setiap mapping yang memiliki source atau sumber. Contoh kueri pada Tabel 4 menunjukkan salah satu sampel kueri yang dijalankan pada DBMS pada tahapan pengujian proses ETL. Keterangan dari contoh kueri tersebut dapat dilihat pada Tabel 5.

Tabel 4 Kasus uji keseimbangan data

\begin{tabular}{|c|c|c|c|}
\hline Kode & Deskripsi & Contoh Kueri & Ekspektasi Hasil \\
\hline M-4 & $\begin{array}{l}\text { Mengecek apakah nilai name } \\
\text { pada tabel dim_commodities } \\
\text { sesuai dengan seluruh nama } \\
\text { komoditas pada data sumber }\end{array}$ & $\begin{array}{l}\text { SELECT name FROM } \\
\text { public.dim_commodities }\end{array}$ & $\begin{array}{l}\text { Nama setiap komoditas sesuai } \\
\text { dengan seluruh nama komoditas } \\
\text { pada data sumber }\end{array}$ \\
\hline M-9 & $\begin{array}{l}\text { Mengecek apakah nilai name } \\
\text { pada tabel dim_locations sesuai } \\
\text { dengan seluruh nama lokasi pada } \\
\text { data sumber }\end{array}$ & $\begin{array}{l}\text { SELECT } * \text { FROM } \\
\text { public.dim_locations WHERE } \\
\text { parent_id=33 AND name='Kab. } \\
\text { Kepulauan Riau' }\end{array}$ & $\begin{array}{l}\text { Nama pada tabel dim_locations } \\
\text { sama dengan seluruh nama lokasi } \\
\text { pada data sumber }\end{array}$ \\
\hline M-31 & $\begin{array}{l}\text { Mengecek apakah nilai data } \\
\text { harvested_area pada tabel } \\
\text { fact_horticultures sesuai dengan } \\
\text { nilai luas panen pada lokasi, } \\
\text { komoditas dan tahun yang dituju } \\
\text { pada data sumber }\end{array}$ & $\begin{array}{l}\text { SELECT harvested_area FROM } \\
\text { public.fact_horticultures WHERE } \\
\text { location_id=53 AND } \\
\text { commodity_id in }(95,118,141 \text {, } \\
\text { 164) AND time_id=46 }\end{array}$ & $\begin{array}{l}\text { Nilai setiap data harvested_area } \\
\text { pada tabel fact_horticultures } \\
\text { sesuai dengan nilai luas panen } \\
\text { yang dituju pada data sumber }\end{array}$ \\
\hline
\end{tabular}

2 Kasus uji kualitas data

Dalam pembuatan kasus uji untuk kualitas data, dibuat kasus uji untuk tiap aturan kualitas data yang ada pada Tabel 3. Kasus uji yang telah dibuat dapat dilihat pada Tabel 6. Contoh kueri pada setiap kasus uji dalam Tabel 6 menunjukkan salah satu sampel kueri yang yang dijalankan pada DBMS pada tahapan pengujian proses ETL, untuk keterangan contoh kueri tersebut dapat dilihat pada Tabel 7.

Tabel 5 Keterangan kueri uji keseimbangan data

\begin{tabular}{clll}
\hline Kode & \multicolumn{1}{c}{ Tabel uji } & \multicolumn{1}{c}{ Atribut uji } & \multicolumn{1}{c}{ Deskripsi kueri } \\
\hline M-4 & dim_commodities & name & Nama-nama komoditas dari seluruh subsektor \\
M-9 & dim_locations & name & $\begin{array}{l}\text { Nilai luas panen subsektor hortikultura pada komoditas } \\
\text { anyelir, jahe, lidah buaya dan salak di kabupaten Aceh Utara } \\
\text { tahun 2015 }\end{array}$ \\
M-31 & fact_horticultures & harvested_area & $\begin{array}{l}\text { Nilai data produktivitas subsektor hortikultura pada } \\
\text { komoditas anyelir, jahe, lidah buaya dan salak di kabupaten } \\
\text { Aceh Utara tahun 2015 }\end{array}$ \\
& & & \\
\hline
\end{tabular}

Kasus uji berkode TC-1 adalah mencari ketelitian nilai data atau precision, untuk mengetahui precision tersebut digunakan pencarian nilai data yang dilihat memiliki ketelitian paling tinggi dalam atribut dan tabel tertentu untuk diuji, dikarenakan definisi data pada DBMS tidak diisi atau dicantumkan pada penelitian sebelumnya. Kasus uji berkode TC-2 didapatkan dari nilai pada data sumber yang seharusnya memiliki nilai 0 untuk data yang tidak ada, bukan merupakan nilai null. Kasus uji berkode TC-3 menunjukkan bahwa 
data seharusnya tidak ada yang memiliki nilai negatif, melainkan bilangan bulat yang bernilai lebih besar atau sama dengan 0 .

Tabel 6 Kasus uji kualitas data

\begin{tabular}{clll}
\hline Kode & \multicolumn{1}{c}{ Deskripsi } & \multicolumn{1}{c}{ Contoh Kueri } & \multicolumn{1}{c}{ Ekspektasi Hasil } \\
\hline TC-1 & $\begin{array}{l}\text { Mengecek apakah ketelitian nilai } \\
\text { data pada data target sesuai } \\
\text { dengan data sumber }\end{array}$ & $\begin{array}{l}\text { SELECT * FROM public.fact_horticultures } \\
\text { WHERE harvested_area=0.633333333333333 }\end{array}$ & Ada hasil yang keluar \\
TC-2 & $\begin{array}{l}\text { Mengecek apakah ada data yang } \\
\text { memiliki nilai } \text { null }\end{array}$ & SELECT * FROM public.fact_horticultures & Tidak ada hasil yang \\
TC-3 & $\begin{array}{l}\text { Mengecek apakah ada data yang } \\
\text { memiliki nilai negatif }\end{array}$ & $\begin{array}{l}\text { WHERE harvested_area IS NULL } \\
\text { SELECT * FROM public.fact_horticultures } \\
\text { WHERE harvested_area<0 }\end{array}$ & $\begin{array}{l}\text { Tidak ada hasil yang } \\
\text { keluar }\end{array}$ \\
\hline
\end{tabular}

Tabel 7 Keterangan kueri uji kualitas data

\begin{tabular}{cccl}
\hline Kode & \multicolumn{1}{c}{ Tabel uji } & \multicolumn{1}{c}{ Atribut uji } & \multicolumn{1}{c}{ Deskripsi kueri } \\
\hline TC-1 & fact_horticultures & harvested_area & $\begin{array}{l}\text { Nilai data pada luas panen subsektor hortikultura yang } \\
\text { memiliki nilai 0.63333333333333 sebagai batas ketelitian } \\
\text { paling tinggi }\end{array}$ \\
& & & $\begin{array}{l}\text { Nilai data pada luas panen subsektor hortikultura yang } \\
\text { memiliki nilai null }\end{array}$ \\
TC-2 & fact_horticultures & harvested_area & $\begin{array}{l}\text { Nilai data pada luas panen subsektor hortikultura yang } \\
\text { memiliki nilai negatif }\end{array}$ \\
TC-3 & fact_horticultures & harvested_area & \\
\hline
\end{tabular}

\section{Pengujian Proses ETL}

Tahapan ini merupakan pengujian fungsional pada proses ETL yang merupakan bagian dari pengujian data warehouse berdasarkan pada Gambar 1. Tahapan ini dilakukan dengan menguji keseimbangan data dan kualitas data. Pengujian data dilakukan berdasarkan pada kasus uji yang telah dibuat. Berikut pengujian yang dilakukan:

\section{Uji keseimbangan data}

Dalam pengujian keseimbangan data, dilakukan pencarian data pada data sumber dan data target berdasarkan pada kasus uji yang ada pada Tabel 4 untuk dibandingkan kesamaan datanya. Tabel 8 menunjukkan hasil dari pengujian ini, terutama yang memiliki hasil pengujian keseimbangan data dibawah $100 \%$.

Terdapat lima kolom pada hasil pengujian ini, yaitu kode, atribut, tabel, jumlah sampel, pengambilan sampel uji, dan persentase kesamaan. Kode merupakan kode yang sama dengan kasus uji pada Tabel 5 untuk mewakili pengujian setiap kasus uji. Atribut dan tabel menunjukkan atribut dan tabel target pengujian pada DBMS. Jumlah sampel menunjukkan jumlah sampel yang diambil dari data sumber untuk melakukan pengujian pada setiap target. Pengambilan sampel uji merupakan cara atau metode pengambilan sampel uji pada data sumber. Persentase kesamaan merupakan persentase hasil dari proses pengujian kesamaan atau keseimbangan data antara data sumber dengan data pada DBMS.

Ada tiga macam cara untuk melakukan pengambilan sampel uji pada tahapan ini, yaitu pengujian pada seluruh data, random sampling dan systematic sampling. Untuk atribut pada tabel yang didapatkan dari berbagai macam tabel, dapat dilakukan lebih dari satu macam cara pengambilan sampel uji dalam satu kali pengujian. Persentase kesamaan didapatkan dari keberhasilan pengujian kesamaan pada seluruh jumlah sampel data di setiap pengujian, persentase tersebut memiliki ketelitian dua angka dibelakang koma dengan pembulatan ke atas.

Tabel 8 Hasil pengujian keseimbangan data

\begin{tabular}{cllrrr}
\hline Kode & \multicolumn{1}{c}{ Atribut } & \multicolumn{1}{c}{ Tabel } & $\begin{array}{c}\text { Jumlah } \\
\text { sampel }\end{array}$ & $\begin{array}{c}\text { Jumlah } \\
\text { populasi }\end{array}$ & $\begin{array}{c}\text { Persentase sampel } \\
(\%)\end{array}$ \\
\hline M-4 & name & dim_commodities & 195 & 195 & 100.000 \\
M-5 & commodity_type_id & dim_commodities & 18 & 179 & 10.056 \\
M-9 & name & dim_locations & 68 & 556 & 12.230 \\
M-28 & commodity_id & fact_horticultures & 92 & 2335144 & 0.004 \\
M-29 & location_id & fact_horticultures & 28 & 2335144 & 0.001 \\
M-31 & harvested_area & fact_horticultures & 28 & 2335144 & 0.001 \\
\hline
\end{tabular}


Tabel 8 Hasil pengujian keseimbangan data (lanjutan)

\begin{tabular}{|c|c|c|}
\hline Kode & Pengambilan sampel uji & $\begin{array}{c}\text { Persentase } \\
\text { kesamaan }(\%)\end{array}$ \\
\hline M-4 & Seluruh data pada tabel & 91.79 \\
\hline M-5 & Random sampling pada name & 94.40 \\
\hline M-9 & $\begin{array}{l}\text { Data dengan parent_id bernilai } 8 \text { hingga } 41(\mathrm{n}=34) \text {, random sampling untuk name } \\
(\mathrm{n}=2)\end{array}$ & 97.06 \\
\hline M-28 & Seluruh komoditi yang memiliki name berbeda & 97.83 \\
\hline M-29 & $\begin{array}{l}\text { Random sampling pada location }(\mathrm{n}=7) \text {, systematic sampling pada commodity }(\mathrm{N}=92 \text {, } \\
\mathrm{n}=4, \mathrm{k}=23) \text {, random sampling pada year }(\mathrm{n}=1) \text {, random sampling pada } \\
\text { harvested_area }(\mathrm{n}=1)\end{array}$ & 96.43 \\
\hline M-31 & $\begin{array}{l}\text { random sampling pada location }(\mathrm{n}=7), \text { systematic sampling pada commodity }(\mathrm{N}=92 \text {, } \\
\mathrm{n}=4, \mathrm{k}=23) \text {, random sampling pada year }(\mathrm{n}=1)\end{array}$ & 92.86 \\
\hline
\end{tabular}

Pengujian keseimbangan data berdasarkan pada kasus uji berkode M-9 pada Tabel 8 ditunjukkan oleh Gambar 5, Gambar 6 dan Gambar 7. Gambar 5 merupakan data sumber dalam bentuk spreadsheet yang berisi nilai luas panen yang ada di lokasi terpilih, yaitu Kab. Kepulauan Riau. Gambar 6 didapatkan dari kueri yang dijalankan pada DBMS untuk Kab. Kepulauan Riau dan Riau sebagai provinsi atau parent lokasi tersebut. Gambar 7 merupakan daftar lokasi kabupaten pada provinsi Riau yang didapatkan dari tampilan aplikasi SOLAP pada pemilihan lokasi.

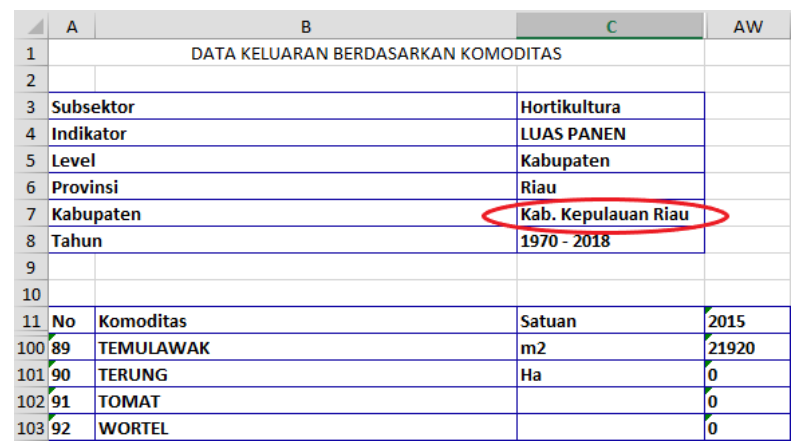

Gambar 5 Nama salah satu lokasi kabupaten dari provinsi Riau, yaitu Kab. Kepulauan Riau pada data sumber.

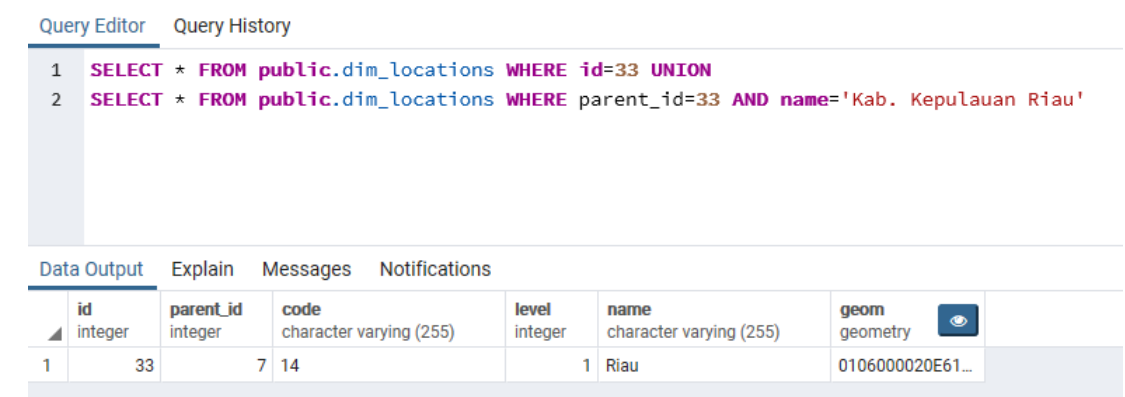

Gambar 6 Pencarian nama salah satu lokasi kabupaten dari provinsi Riau, yaitu Kab. Kepulauan Riau pada DBMS data target. 


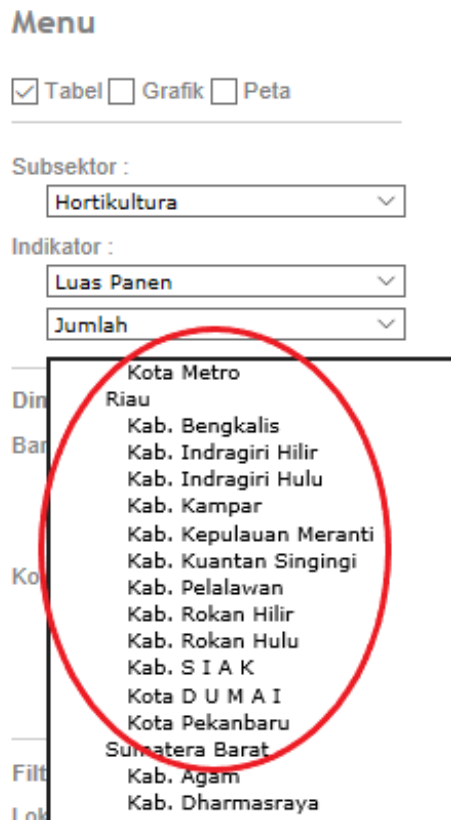

Gambar 7 Daftar nama lokasi kabupaten di provinsi Riau pada tampilan SOLAP.

Perbedaan terlihat pada Gambar 5 yang merupakan data sumber bahwa provinsi Riau memiliki kabupaten bernama Kab. Kepulauan Riau dan memiliki data di dalamnya, yaitu nilai luas panen sedangkan pada DBMS data target dan daftar kabupaten di provinsi Riau pada tampilan aplikasi SOLAP tidak ada Kab. Kepulauan Riau. Hasil keluaran kueri pada DBMS data target yang dapat dilihat pada Gambar 6 seharusnya menunjukkan record data lokasi Kab. Kepulauan Riau pada baris kedua, namun tidak muncul. Lalu, Gambar 7 menunjukkan daftar lokasi kabupaten di provinsi Riau pada tampilan aplikasi SOLAP tidak memiliki kabupaten Kepulauan Riau.

Pengujian keseimbangan data berdasarkan pada kasus uji berkode M-31 pada Tabel 8 ditunjukkan oleh Gambar 8, Gambar 9 dan Gambar 11. Gambar 8 merupakan keluaran hasil data yang didapatkan dari data sumber dalam bentuk spreadsheet. Pencarian data target pada DBMS dapat dilihat pada Gambar 9 dengan keterangan id komoditas pada Gambar 10 dan tampilan SOLAP dapat dilihat pada Gambar 11. Data target pada DBMS didapatkan dengan menjalankan kueri pada DBMS, sedangkan data target pada tampilan SOLAP didapatkan dengan memilih kategori subsektor dan indikator, memilih dimensi baris dan kolom, dan melakukan filter yang ada pada tampilan situs SOLAP untuk mendapatkan data yang diinginkan.

\begin{tabular}{|c|c|c|c|c|}
\hline 4 & A & B & C & AW \\
\hline 1 & \multicolumn{3}{|c|}{ DATA KELUARAN BERDASARKAN KOMODITAS } & \\
\hline 2 & & & & \\
\hline 3 & \multicolumn{2}{|c|}{ Subsektor } & Hortikultura & \\
\hline 4 & \multicolumn{2}{|c|}{ Indikator } & LUAS PANEN & \\
\hline 5 & \multicolumn{2}{|c|}{ Level } & Kabupaten & \\
\hline 6 & \multicolumn{2}{|c|}{ Provinsi } & Aceh & \\
\hline 7 & \multicolumn{2}{|c|}{ Kabupaten } & Kab. Aceh Utara & \\
\hline 8 & \multicolumn{2}{|c|}{ Tahun } & 1970 - 2018 & \\
\hline \multicolumn{5}{|l|}{9} \\
\hline \multicolumn{5}{|l|}{10} \\
\hline 11 & No & Komoditas & Satuan & 2015 \\
\hline 19 & 8 & ANYELIR & & 0 \\
\hline 42 & 31 & JAHE & M2 & 144243 \\
\hline 65 & 54 & LIDAH BUAYA & $\mathrm{m} 2$ & 478 \\
\hline 88 & 77 & SALAK & $\mathrm{Ha}$ & 0 \\
\hline
\end{tabular}

Gambar 8 Nilai luas panen sampel komoditas subsektor hortikultura di kabupaten Aceh Utara tahun 2015 pada data sumber. 


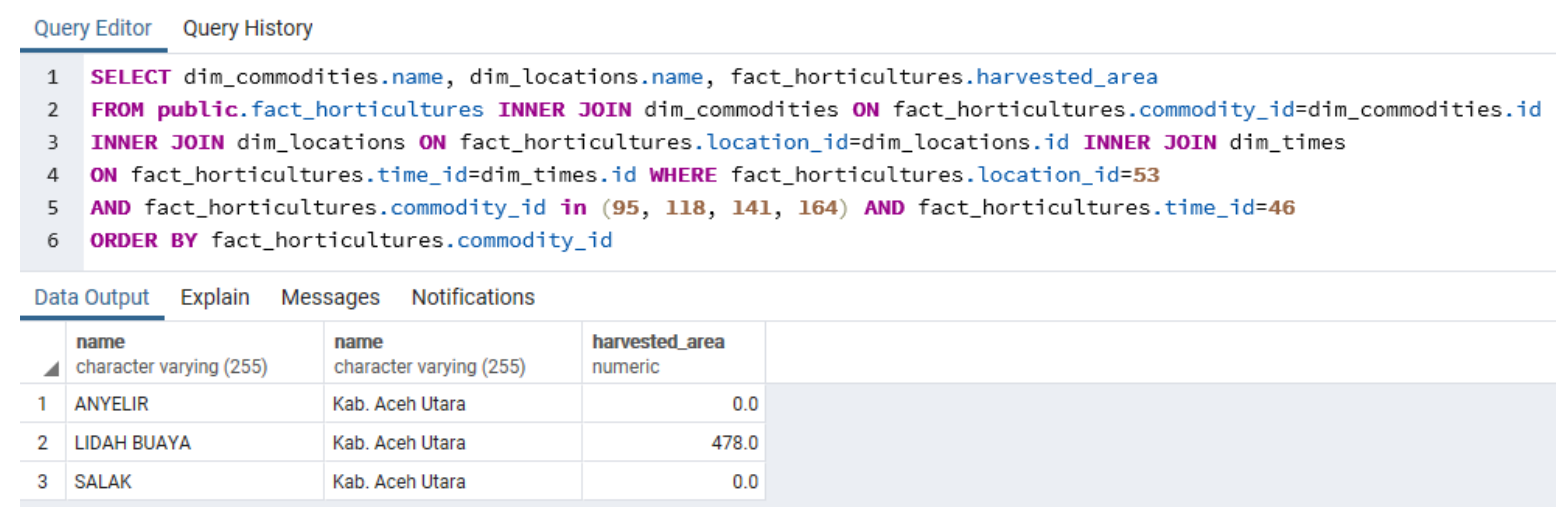

Gambar 9 Hasil kueri luas panen sampel komoditas subsektor hortikultura di kabupaten Aceh Utara tahun 2015 pada DBMS dengan keterangan nama komoditas, lokasi dan tahun.

\begin{tabular}{l|r|l|l|l|l|l}
\hline 1 & SELECT * FROM public.dim_commodities WHERE id in $(95,118,141,164)$ \\
\hline
\end{tabular}

Gambar 10 Nilai nama pada id komoditas yang dijalankan pada kueri DBMS.

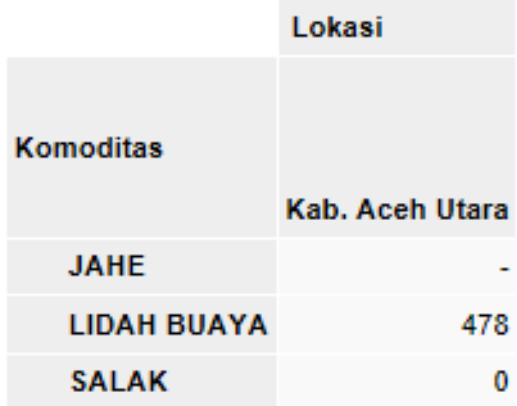

Gambar 11 Nilai luas panen sampel komoditas subsektor hortikultura di kabupaten Aceh Utara tahun 2015 pada tampilan SOLAP.

Gambar 11 menunjukkan beberapa perbedaan hasil antara data sumber dengan DBMS data target dan tampilan SOLAP. Terlihat pada data sumber menunjukkan hasil luas panen beberapa sampel komoditas terpilih, termasuk komoditas jahe, sedangkan pada DBMS data target dan tampilan aplikasi SOLAP tidak terlihat komoditas jahe. Pada data sumber dan DBMS data target juga terlihat komoditas anyelir, sedangkan pada tampilan SOLAP tidak terlihat.

\section{Uji Kualitas Data}

Dalam pengujian kualitas data, dijalankan masing-masing kueri yang tertera pada Tabel 6 pada DBMS data target, masing-masing kueri kasus uji dijalankan pada setiap atribut dalam tabel tertentu yang memiliki kriteria kualitas data yang sama. Tabel 9 merupakan hasil dari pengujian kualitas data yang memiliki keluaran salah satu tingkat keberhasilan, yaitu berhasil atau tidak berhasil. 
Tabel 9 Hasil pengujian kualitas data

\begin{tabular}{cclll}
\hline Kode & Kode kasus uji & \multicolumn{1}{c}{ Atribut } & \multicolumn{1}{c}{ Tabel } & Keberhasilan \\
\hline Q-1 & TC-1 & harvested_area & fact_horticultures & Berhasil \\
Q-2 & TC-1 & production & fact_horticultures & Berhasil \\
Q-18 & TC-2 & harvested_area & fact_horticultures & Tidak berhasil \\
Q-19 & TC-2 & production & fact_horticultures & Tidak berhasil \\
Q-35 & TC-3 & harvested_area & fact_horticultures & Berhasil \\
Q-36 & TC-3 & production & fact_horticultures & Berhasil \\
\hline
\end{tabular}

Pada Tabel 9 tertera hasil kueri pengujian kualitas data berkode Q-1 sebagai sampel dari kasus uji berkode TC-1, yaitu pengujian ketelitian nilai data. Hasil kueri tersebut menunjukkan ada data yang ditampilkan seperti pada Gambar 12, maka ketelitian data pada atribut harvested_area dalam tabel fact_horticultures sesuai dengan ketelitian data pada data sumber.

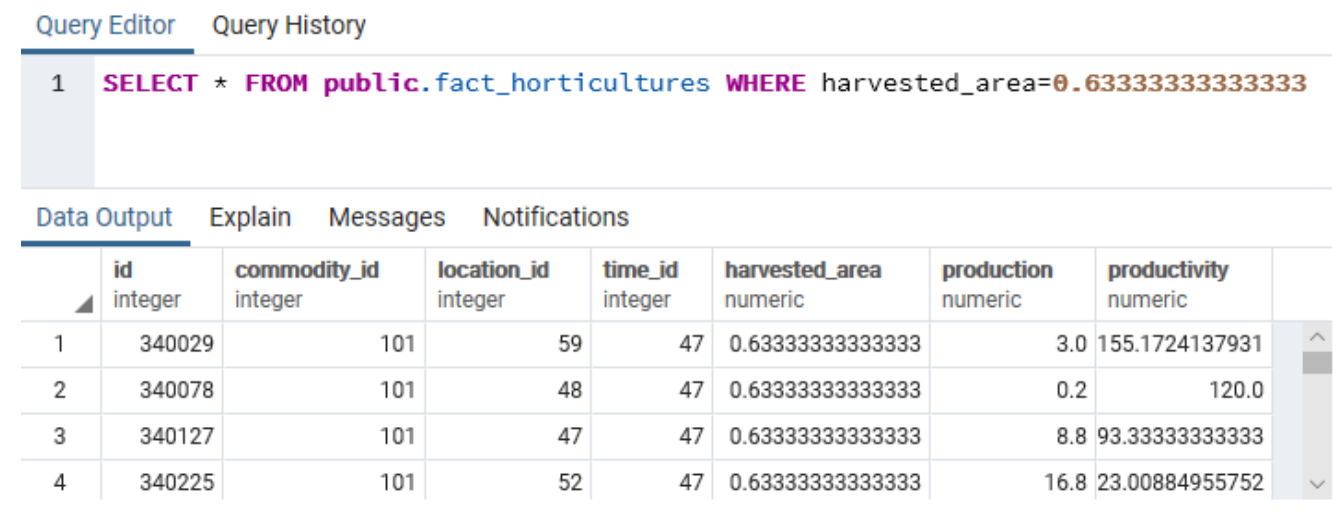

Gambar 12 Hasil kueri pengujian ketelitian nilai data.

Uji kualitas data yang dilakukan selanjutnya adalah pengujian kualitas data berkode Q-18 sebagai sampel dari kasus uji berkode TC-2, yaitu pengujian nilai data yang bernilai null. Hasil pengujian tersebut dapat dilihat pada Gambar 13. Hasil kueri pada Gambar 13 menunjukkan bahwa ada data yang keluar, jadi pengujian kualitas data berkode Q-13 dinyatakan tidak berhasil karena pada DBMS data target terdapat data yang memiliki nilai null atau tidak sesuai ekspektasi yang ada pada Tabel 6.

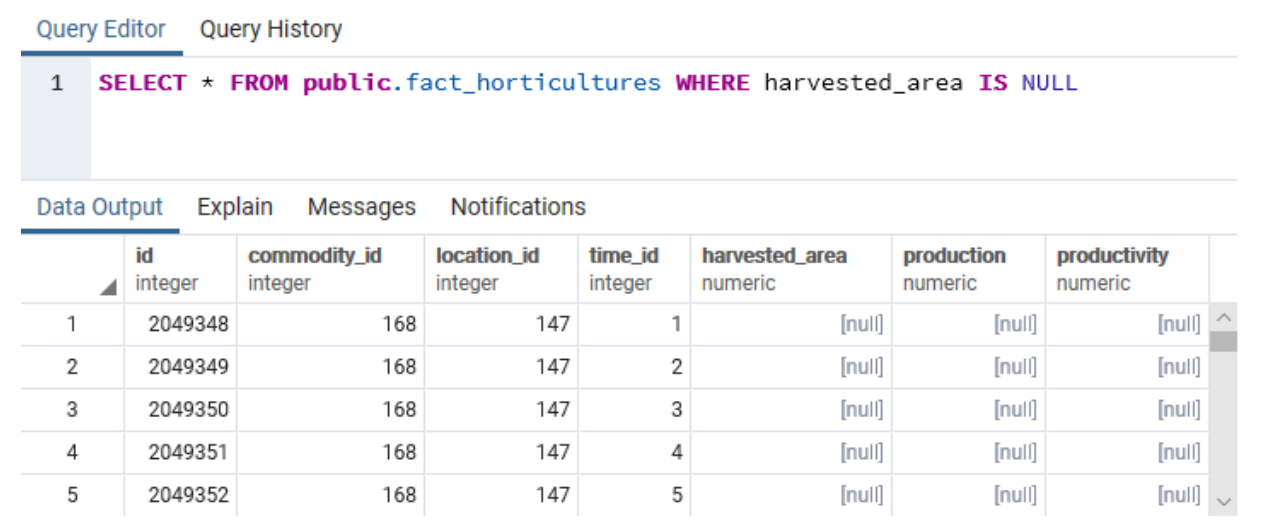

Gambar 13 Hasil kueri pengujian nilai data bernilai null.

\section{Analisis Hasil Uji}

Pada tahapan ini, dilakukan analisis terhadap pengujian proses ETL. Dari pengujian proses ETL terlihat bahwa ada kesalahan pada uji kualitas data dan uji keseimbangan data dari hasil yang diharapkan. Setelah dianalisis, penyebab kesalahan pada data warehouse bukan hanya terletak pada proses ETL, namun juga ada kesalahan pada pengambilan data sumber dan pada pengembangan aplikasi tampilan SOLAP. Kesalahan pada pengembangan dijelaskan sebagai berikut. 
1 Pengambilan data sumber

Pada uji kualitas data berkode Q-18 pada Gambar 14, terlihat bahwa ada data yang berisi $n u l l$, sedangkan ekspektasinya tidak ada karena dilihat dari kebanyakan nilai data pada data sumber, jika tidak ada data yang tercatat, nilai akan berisi angka bernilai 0 , bukan null. Namun, setelah dilakukan peninjauan ulang terhadap data sumber, ternyata menurut Gambar 14, data sumber yang merupakan spreadsheet tersebut tidak menampikan data. Kesalahan tersebut dinyatakan sebagai kesalahan pada pengambilan sumber data, bukan kesalahan pada proses ETL.

\begin{tabular}{|c|c|c|c|c|}
\hline \multicolumn{2}{|c|}{ Subsektor } & Hortikultura & & \\
\hline \multicolumn{2}{|c|}{ Indikator } & PRODUKTIVITAS & & \\
\hline \multicolumn{2}{|c|}{ Level } & Kabupaten & & \\
\hline \multicolumn{2}{|c|}{ Provinsi } & Papua & & \\
\hline \multicolumn{2}{|c|}{ Kabupaten } & Kab.Mamberamo & & \\
\hline \multicolumn{2}{|c|}{ Tahun } & $1970-2018$ & & \\
\hline No & Komoditas & Satuan & 1970 & 1971 \\
\hline 1 & ADENIUM & & & \\
\hline 2 & AGLAOENEMA & & & \\
\hline 3 & ALPUKAT & & & \\
\hline 4 & ANGGREK & & & \\
\hline 5 & ANGGUR & & & \\
\hline
\end{tabular}

Gambar 14 Potongan hasil data sumber yang memiliki nilai null pada DBMS.

\section{Proses ETL}

Pada perbedaan antara data sumber dan data target DBMS dalam uji keseimbangan data dan uji kualitas data terdapat beberapa kesalahan proses ETL yang terlihat. Dari seluruh pengujian kesimbangan data yang mempunyai hasil dibawah $100 \%$ dan pengujian kualitas data yang tidak berhasil, penyebab-penyebab kesalahan tersebut dianalisis. Kesalahan pertama terlihat pada Gambar 6 yang merupakan perbedaan nama lokasi kabupaten Kepulauan Riau, yaitu tidak adanya kabupaten tersebut, walaupun tercatat nilai luas panen di dalam kabupaten tersebut pada data sumber. Setelah dianalisis, seperti yang terlihat pada Gambar 15, nilai luas panen komoditas temulawak pada lokasi tersebut pada tahun 2015 tetap tercatat di dalam DBMS, namun id lokasi yang tercantum pada komoditas hortikultura tersebut tidak memiliki nilai atau nama lokasi. Penyebab kesalahan ini disebabkan karena nama lokasi kabupaten-kabupaten di Indonesia pada DBMS mengacu pada Badan Informasi Geospasial (BIG) Republik Indonesia yang memiliki perbedaan dengan nama lokasi yang ada pada data sumber. Berdasarkan pada BIG, di dalam provinsi Riau tidak ada kabupaten Kepulauan Riau.

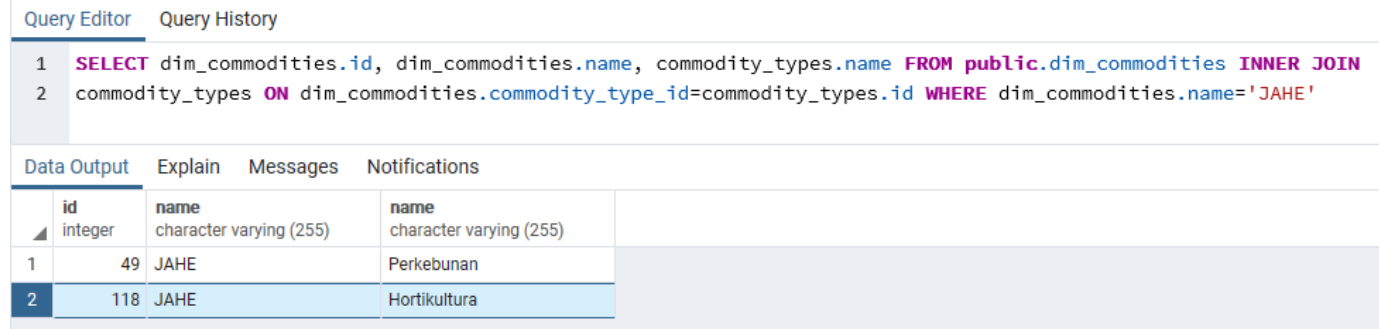

Gambar 15 Hasil pencarian komoditas jahe dalam tabel dim_commodities pada DBMS beserta keterangan subsektornya.

Kesalahan kedua terlihat pada perbedaan pada komoditas jahe yang tidak ada pada DBMS seperti pada Gambar 9. Setelah dilakukan analisis, terdapat dua komoditas jahe pada tabel dim_commodities dengan subsektor berbeda seperti yang terlihat pada Gambar 16. Id komoditas jahe yang terdaftar pada tabel fact_horticultures merupakan id komoditas jahe yang tergolong dalam kategori perkebunan, sedangkan seharusnya id komoditas jahe yang terdaftar berkategori hortikultura, jadi hasil keluaran dari kueri tersebut tidak menampilkan komoditas jahe. Hal itu disebabkan data target dari data sumber yang berisi tabel subsektor 
hortikultura dimuat berdasarkan nama komoditas, sehingga komoditas jahe yang mempunyai id terkecil yang terpilih, yaitu komoditas jahe dengan subsektor perkebunan. Penyebab kesalahan tersebut dibuktikan dengan kesalahan yang sama pada komoditas kapulaga pada tabel fact_horticultures.

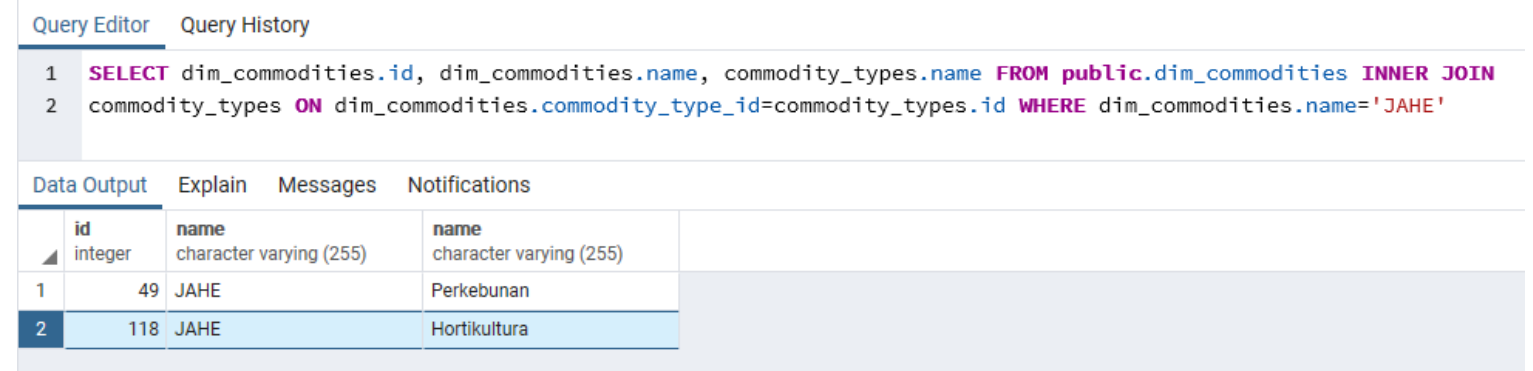

Gambar 16 Hasil pencarian komoditas jahe dalam tabel dim_commodities pada DBMS beserta keterangan subsektornya.

\section{Tampilan aplikasi SOLAP}

Pada data target tampilan SOLAP terdapat komoditas jahe namun bernilai null, kesalahan pada proses ETL sebelumnya terlihat dalam tampilan SOLAP, hal ini dikarenakan pengembang menggunakan komoditas jahe yang berkategori hortikultura namun tidak terdata dalam tabel fact_horticultures. Perbedaan juga terjadi pada komoditas anyelir yang tidak terdata pada tampilan SOLAP seperti pada Gambar 11, kesalahan ini dinyatakan sebagai kesalahan pada pengembangan aplikasi tampilan SOLAP, hal ini dikarenakan komoditas tersebut tidak ada di dalam kategori hortikultura, namun masuk ke dalam kategori hortikultura tanaman hias, sedangkan pada DBMS dan data sumber, komoditas adenium masuk ke dalam kedua kategori tersebut.

\section{SIMPULAN}

Penelitian ini telah menguji modul ETL berdasarkan penelitian sebelumnya untuk mengetahui letak kesalahan pada pengembangan modul tersebut. Penelitian ini menghasilkan letak kesalahan pengembangan modul berdasarkan uji kualitas data dan uji keseimbangan data yang dilakukan dengan mengambil sampel data sumber dan data target, kemudian dianalisis. Pengambilan sampel cukup mewakili data secara keseluruhan dan ditemukan ketidaksesuaian antara data sumber dan data target. Dari hasil analisis ditemukan letak kesalahan pada pengembangan tidak hanya pada proses ETL, namun ditemukan juga kesalahan pada pengambilan data dari sumber dan pada pengembangan aplikasi tampilan SOLAP komoditas pertanian Indonesia. Pengujian pada penelitian ini hanya melakukan pengujian pada proses ETL, namun data warehouse sebaiknya dilakukan dalam setiap tahapan dalam pengembangan data warehouse, sehingga data warehouse yang telah selesai dikembangkan dapat langsung digunakan dengan pengguna data warehouse untuk mencapai tujuan penggunaan data dengan hasil yang akurat.

\section{DAFTAR PUSTAKA}

Boulil K, Bimonte S, Pinet F. 2014. Spatial OLAP integrity constraints: From UML-based specification to automatic implementation: Application to energetic data in agriculture. Journal of Decision Systems. 23(4): 460-480.

Caron, E. 2013. Explanation of exceptional values in multi-dimensional business databases [tesis]. Rotterdam (NL): Erasmus University Rotterdam.

ElGamal N, El-Bastawissy, A, Galal-Edeen, G. 2011. Towards a data warehouse testing framework. Di dalam: 2011 Ninth International Conference on ICT and Knowledge Engineering; Bangkok, 2012 Jan 12-13. Bangkok (TH). hlm: 65-71. 
Golfarelli M, Rizzi S. 2009. Comprehensive approach to data warehouse testing. Di dalam: Proceedings of the ACM twelfth international workshop on Data warehousing and OLAP; Hong Kong, 2009 Nov 6. Hong Kong (HKG). hlm: 17-24.

Homayouni H. 2018. An approach for testing the Extract-Transform-Load process in data warehouse systems [tesis]. Colorado (US): Colorado State University.

Homayouni H, Ghosh S, Ray I. 2018. Data warehouse testing. Di dalam: Advance in Computers. Amsterdam (NLD): Elsevier.

Patel S. 2012. What is data warehouse?. IJAITI. 1(4).

Sitanggang IS, Trisminingsih R, Fuady F, Khotimah H. 2016. Extract, transform, load module in SOLAP for Indonesia agricultural commodity. Di dalam: 2018 International Conference on Sustainable Information Engineering and Technology (SIET); Malang, 2018 Nov 10. Malang (ID). hlm: 101-105.

Sitanggang IS, Trisminingsih R, Khotimah H, Syukur M. 2018. Usability testing of SOLAP for Indonesia agricultural commodity. Di dalam: Proceedings of the $5^{\text {th }}$ International Seminar on Sciences; Yogyakarta, 2019 Okt 25. Yogyakarta (ID). hlm: 1-8.

Wijaya R, Pudjoatmodjo B. 2016. Penerapan extraction-transformation-loading (ETL) dalam data warehouse (studi kasus: departemen pertanian). Jurnal Nasional Pendidikan Teknik Informatika (JANAPATI). 5(2): 61. 